\title{
Neurolmages
}
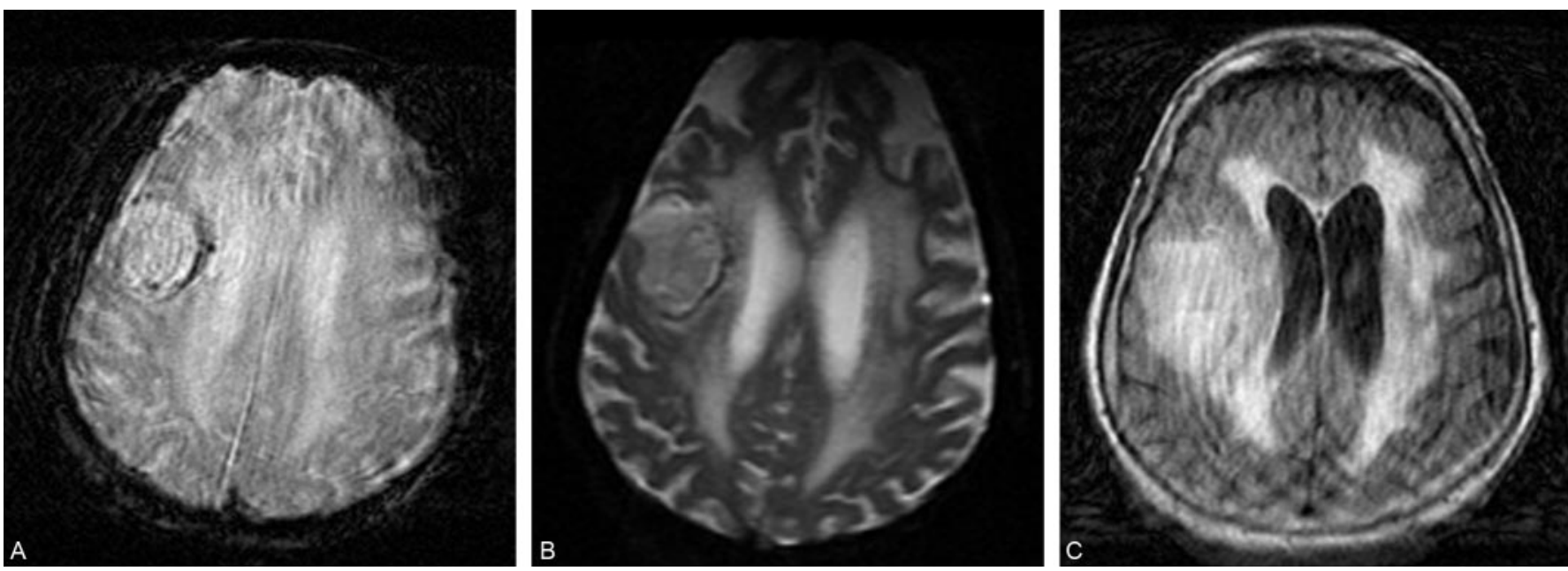

Figure. (A) Gradient echo (GRE), (B) T2-weighted imaging (diffusion weighted MRI $b=0$ ) and (C) FLAIR showed right hemisphere hyperintensity with a slight rim of hypointensity on GRE and T2, consistent with an accumulation of fresh arterial blood consisting mainly of intact red blood cells containing oxy-Hb. Oxy-Hb is diamagnetic showing hypo or isointensity on T1-weighted imaging and hyperintensity on T2-weighted imaging (high water content).

\section{Hyperacute post-thrombolysis hematoma by MRI}

A.J. Gagnon, MD, FRCPC, and P.A. Barber, MB ChB, MRCP, Calgary, Alberta, Canada

An 89-year-old woman presented acutely following the onset of aphasia and right hemiparesis (NIH Stroke Scale $=10)$, without clinical or CT contraindications to thrombolysis. She received IV recombinant tissue plasminogen activator $(0.9 \mathrm{mg} / \mathrm{kg}$ infused over 1 hour after $10 \%$ bolus) beginning 90 minutes after symptom onset.

Address correspondence and reprint requests to Dr. A.J. Gagnon, University of Calgary, Calgary Stroke Program, 1403-29 Street NW, Calgary, Alberta T2N 2T9, CANADA; e-mail: alexis.gagnon@calgaryhealthregion.ca
The patient was imaged with a 3 T MRI 2.5 hours after stroke onset. Ten minutes after the start of the MRI, she suddenly became agitated and developed contralateral left hemiplegia. Fluid attenuated inversion recovery (FLAIR), T2-weighted and gradient echo sequences revealed a hyperacute right hemisphere hematoma (figure). ${ }^{1}$ Microbleeds, a potential risk factor for contralateral symptomatic hemorrhage following thrombolysis, were not identified on gradient echo sequences. ${ }^{2}$

1. Parizel PM, Makkat S, Van Miert E et al. Intracranial hemorrhage: principles of CT and MRI interpretation. Eur Radiol 2001;11:1770-1783.

2. Kidwell CS, Saver JL, Villablanca P et al. Magnetic resonance imaging detection of microbleeds before thrombolysis: an emerging application. Stroke 2002;33:95-98. 


\section{Neurology}

\section{Hyperacute post-thrombolysis hematoma by MRI}

A. J. Gagnon and P. A. Barber

Neurology 2004;63;1534

DOI 10.1212/01.WNL.0000137024.44831.28

\section{This information is current as of October 25, 2004}

\section{Updated Information \&} Services

References

Subspecialty Collections

Permissions \& Licensing

Reprints including high resolution figures, can be found at: http://n.neurology.org/content/63/8/1534.full

This article cites 2 articles, 1 of which you can access for free at: http://n.neurology.org/content/63/8/1534.full\#ref-list-1

This article, along with others on similar topics, appears in the following collection(s):

\section{All Cerebrovascular disease/Stroke}

http://n.neurology.org/cgi/collection/all_cerebrovascular_disease_strok

e

Intracerebral hemorrhage

http://n.neurology.org/cgi/collection/intracerebral_hemorrhage

MRI

http://n.neurology.org/cgi/collection/mri

Information about reproducing this article in parts (figures,tables) or in its entirety can be found online at:

http://www.neurology.org/about/about_the_journal\#permissions

Information about ordering reprints can be found online:

http://n.neurology.org/subscribers/advertise

Neurology ${ }^{\circledR}$ is the official journal of the American Academy of Neurology. Published continuously since 1951, it is now a weekly with 48 issues per year. Copyright . All rights reserved. Print ISSN: 0028-3878. Online ISSN: 1526-632X.

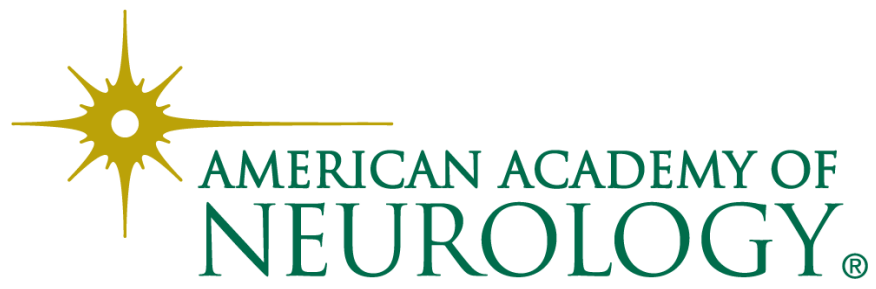

